6 | 1986

Par où passe la technologie II

\title{
Les outils préhistoriques. Leur évolution
}

\section{Charles Frémont}

\section{OpenEdition}

Journals

Édition électronique

URL : https://journals.openedition.org/tc/939

DOI : $10.4000 /$ tc. 939

ISSN : 1952-420X

\section{Éditeur}

Éditions de l'EHESS

\section{Édition imprimée}

Date de publication : 1 février 1986

ISSN : 0248-6016

\section{Référence électronique}

Charles Frémont, « Les outils préhistoriques. Leur évolution », Techniques \& Culture [En ligne], 6| 1986, mis en ligne le 24 janvier 2006, consulté le 29 septembre 2022. URL : http://journals.openedition.org/ tc/939; DOI : https://doi.org/10.4000/tc.939

Ce document a été généré automatiquement le 29 septembre 2022.

Tous droits réservés 


\section{Les outils préhistoriques. Leur évolution}

Charles Frémont 